\title{
An empirical assessment of willingness to accept "low-cost" air transport services: Evidence from the Middle East
}

\author{
Sanaz Vatankhah \\ Ahvaz Branch, Islamic Azad University, Ahvaz, Iran \\ Mansour Zarra-Nezhad \\ Shahid Chamran university of Ahvaz, Ahvaz, Iran \\ Ghanbar Amirnejad \\ Shushtar Branch, Islamic Azad University, Shushtar, Iran
}

Received: 27 April 2019. Revision received: 22 May 2019. Accepted: 29 May 2019.

\begin{abstract}
The purpose of this study is to investigate passengers' preferences and willingness to accept low-cost air transport services. Choice experiment was applied to examine passenger choices associated with a bundle of service attributes applicable to low-cost air transport service. Results of multinomial logit models demonstrated that passengers are willing to accept low-cost air transport services and their preferences are significantly associated with their socio-economic characteristics and travel behavior. Airline managers and policy makers are encouraged to pay closer attention to the appealing nature of low-cost air transport services while accounting for the significant role of passengers' socio-demographic characteristics and travel behavior. This study contributes to the relative body of knowledge through offering willingness to accept calculation as a strategic tool to assess the feasibility of low-cost air transport provision in developing and less developed countries where such services are yet unavailable.
\end{abstract}

Key Words: Low-cost carrier, stated preference, choice experiment, willingness to accept, Iran.

\section{JEL Classification: M390; M000}

\section{Introduction}

Air transport services are booming globally and the demand for air travel is dramatically increasing each year making air transport operation a significant pillar of economic growth and competitiveness (Stichhauerova and Pelloneova, 2019). To survive in this fragmented market place, therefore, airlines should acquire a competitive position. One possible way of achieving competitive advantage is the adoption of creative business model which violates the traditional ways of getting the-job- done. According to Johnson, Christensen and Kagerman (2008), several situations would call for a modification in business models. That is, providing service offerings which is appealing to a wider range of actual and potential customers who have been neglected previously, as existing solutions were somehow complicated or expensive for them. Emergence of low-cost carriers (LCCs) is a clear example of changing stablished ways of getting a job done (i.e. air transport services). Emergence of LCCs dates back to 1970s in the United States perusing a low-cost strategy to create and offer lower fares (Francis, Dennis, Ison and 
Humphreys, 2007). It appears that air transport services which are offered by LCCs stimulate the demand of both tourism market (Grigolon, Kemperman and Timmermans, 2012) and the business travelers (Brons, Pels, Nijkamp and Rietveld 2002). According to Fleischer, Peleg and Byk (2011), emergence of LCCs in travel scene pursuing no thrillsvery low price strategy led to bouncing competition with full service careers and caused an extended choice sets for travelers. Against its vast expansion (Dobruszkes, 2006; Han, 2013; Zhang, Hanaoka, Inamura and Ishikura, 2008), however, LCCs have not been fully entered into Asian market (Zhang et al., 2008). This is specially the case for Iran where no LCC has penetrated into its air transport market while several LCCs namely fly Dubai, air Arabia, Pegasus, air Asia and Sun express are currently operating in this region with annual increase in number of flights (\%4 increase), passengers (\%9.7 increase), cargo (\%27.3 increase) and air post (\%4.6 increase) (Iran Civil Aviation report, 2018). According to Van Cranenburgh, Chorus and Van Wee (2014) high travel costs (e.g. high air ticket fare) negatively affect the willingness to go on a travel. Moreover, CastilloManzano, López-Valpuest and González-Laxe (2011) assert that the emergence of LCCs significantly affected the development of tourism flow. Accordingly, to nurture tourism development, it seems plausible to develop low-cost business model for countries in which its airline industry suffers from the lack low-cost air transport services. To shift from existing full-service airline business model, therefore, there must be a detailed understanding of passengers' expectations to provide proper airline services (Kurtulmuşoğl, Can and Tolon, 2016; Pels, Nijkamp and Rietveld, 2003; Jung and Yoo, 2014). Past researches have pointed out the factors influencing passengers' choice of air travel services (e.g. Adeola and Adebiyi, 2014; Dennett, Ineson, Stone and Colgate, 2000; Jung and Yoo, 2014; Ong and Tang, 2010; Yoo and Ashford, 1996 ), nevertheless, the phenomenon of LCCs in tourism and travel research received little attention (Akamavi, Mohamed, Pellmann and Xu, 2015; Alamdari and Black,1992; Casey, 2010) and there is a paucity of research pertaining to factors identifying why and how passengers would choose an airline to fly with (Chen and Chao, 2015; Kim and Park, 2017; Medina-Muñoz, Medina-Muñoz and Suárez-Cabrera, 2018). This study would provide a guideline to assess low-cost air transport attribute choice and feasibility in developing and less developed countries where the knowledge of low-cost air transportation is still in its infancy.

Against this backdrop, the aim of this study is to analyze factors determining passengers' preferences regarding air transport services. Applying a survey based choice experiment (CE), this study endeavors to identify whether and how, specific air transport service attributes manifested by ticket fare, frequent flyer program (FFP), food and beverage $(F \& B)$ services, ground services, flexibility, frequency and punctuality would act as determining factors affecting passengers' air transport choice. Particularly this study analyses respondents' willingness to accept (WTA) low-cost air travel services by estimating marginal rate of substitution between associated changes in ticket fare and the remaining air travel service attributes mentioned above. WTA refers to the minimum amount a consumer is willing to accept to sacrifice a specific product or service (Hanemann, 1991). In spite of the extensive attention paid to the importance of consumers' preference, "Willingness-to-accept (WTA) questions have been largely abandoned in stated preference empirical work in favor of eliciting willingness-to-pay (WTP) responses" (Lloyd-Smith and Adamowicz, 2018, p. 133). Accordingly, number of multinomial logit (MNL) models have been calibrated to estimate passengers' WTA lowcost air transport services. The use of MNL model is warranted in relative literature (e.g. 
Basu and Hunt, 2012; Chang and Sun, 2012; Grigolon et al., 2012; Hess, Adler and Polak, 2007).

\section{Literature review}

\subsection{Airline choice}

Review of extant literature reveals that several factors in terms of fare (Koo, Caponecchia and Williamson, 2018), air travel service quality (Adeola and Adebiyi, 2014), frequent flyer program (Dennett et al., 2000), airline image (Connor and Davidson, 1997), flight frequency (Hess and Polak, 2006), perceived flight safety (Fleischer, Tchetchik and Toledo, 2015; Koo, et al., 2015; 2018) and booking method (Ong and Tang, 2010) are among important factors influencing passengers' choice of an airline. Particularly, Jung and Yoo (2014) studied passengers' choice of an airline in a domestic short-haul travel and found that fare, access time and journey time are significant predictors of passengers' choice in Korea. According to Yoo and Ashford (1996), journey time, air fare, service frequency, and nationality of airline are important factors in determining passengers' choice of an airline for flights more than 10 hours. More relevant to this study, Han (2013) studied several attributes of a low-cost air travel and found that air quality, temperature, layout, and amenities significantly affect passengers' satisfaction and behavioral intentions. In addition, demographic (e.g. educational level), socioeconomic (e.g. income level), travel behavior (e.g. ticket buying method) and destination characteristics (e.g. destination airport) have been found to be significantly associated with passengers' choice of an airline (Chang and Sun, 2012; Chen and Chao, 2015; Medina-Muñoz et al., 2018; Gilbert and Wong, 2003; Park, 2007; Yaylali, Çelik and Dilek, 2016). It is assumed that the demand for air travel is highly influenced by passengers' socio-demographic attributes (Chang and Sun, 2012; Gilbert and Wong, 2003; Park, 2007). Milioti, Karlaftis and Akkogiounoglou (2015) reported that passengers choose an airline for its better fares, higher safety and reliability as well as its friendlyand-helpful staff during flight. An in-depth review of current literature regarding passengers' choice of airline is presented in appendix. Emergence of low-cost careers triggered both an increased demand for air transport services and the development of airports (Kalinowski, 2014) while experiencing tremendous expansion in share of passengers and increased scale of passenger transportation operations (Augustyniak, 2014). Under these circumstances, low-cost model of air transport operation is deemed research worthy. Despite the existence of a vast literature pertaining to the factors affecting passengers' choice, however, the significant impact of ticket fare vis-a-vis other important attributes is yet unexplored. Specifically, the joint impact of LCCs attributes have not been investigated in a single empirical study. It appears that, discrete choice models are handful solutions in valuing travel attributes (Cirillo and Axhausen, 2006; Hensher, 2001; Jara-Díaz and Guevara,2003). The application of discrete choice models (e.g. MNL model) is also warranted among researchers to identify potential demand for air travel behavior (e.g. Alamdari and Black, 1992; Jung and Yoo, 2014; Van Cranenburgh et al., 2014; Yaylali et al., 2016). Based on a stated preference survey data, this study calibrates MNL models to explore passengers' preferences of airline choice determinants as well as the impact of their socio-economic characteristic (Gilbert and Wong, 2003) and travel behavior (Chen and Chao, 2015) in choosing a preferred airline. To do so, 7 important attributes which are significantly highlighted in LCCs business 
model namely fare, flexibility, frequency, punctuality, FFP, F\&B services and ground services will be analyzed (Casey, 2010; Govindarajan and Kopalle, 2006; Graham and Shaw, 2008; Kumar, 2006; Lawton, 2003; Marcus and Anderson, 2008; Mason and Alamdari, 2007; O'Connell and Williams, 2005; Ryan and Birks, 2006; Wensveen and Leick, 2009). This paper would extend the existing knowledge on passengers' airline choice by identifying how specific characteristics of LCCs would stimulate the demand for a low-cost air travel service. Particularly, this study estimates respondents' WTA lowcost air transport service conditioned on their socio-economic as well as their travel behavior characteristics. Whilst the current study shed light on policy makers' disposition to surpass transportation offerings in developing countries where low-cost air travel is yet unavailable, this study would also offer choice modelling as a strategic tool to identify the feasibility of new air transport service offerings. The results would further contribute to the managerial sphere where practitioners are struggling to find a competitive position in the airline industry.

\subsection{Utility theory}

Every day, individuals are facing situations in which they are forced to make a decision. Decisions can be simple as deciding to drink water or cola while feeling thirsty or be complicated like which brand of a car is more appropriate to buy. In all, several considerations should be made to come up with the best possible choice. It appears that a number of theories may be appropriate to explain individuals' decision making behavior. However, the theory can best describe behavior which triggers descriptive, abstract and operational actions (Ben-Akiva and Lerman, 1985). According to Ben-Akiva and Lerman (1985), each decision is made under a sequential decision making process:

1. Choice problem statement

2. Alternatives generation

3. Alternatives' attributes evaluation

4. Choice

5. Action

Therefore, it appears that, decisions are not only taken based on the alternatives, but they are also associated with the attributes of those alternatives (Luce, 2005). Finally, Ben-Akiva and Lerman (1985), assert that individuals make decision following decision rules which help them choose from several possible alternatives, of which utility model seems to be more common in discrete choice literature (Alamdari and Black, 1992; Basu and Hunt, 2012; Louviere, Hensher and Swait, 2000). According to this rule, an alternative seems to be attractive to decision maker if the vector defining an objective function displays the attractiveness of that specific alternative's attribute. Therefore, this attractiveness which is called utility in literature, is a measure that the decision maker is trying to maximize while making a decision. According to Lancaster (1966), the utility function is $U i n=U(\boldsymbol{x i n})$ including $\boldsymbol{X} i n$ as the vector of the attribute values, for every alternative represented as $i$ by every decision maker displayed by $n$.

\section{Methods}

\subsection{The MNL model specification}


As stated earlier, this study applies CE which considers the attributes associated with respondents' choice of air travel service in alternative $j$ in choice set $c$. The alternative $j$ represents a specific combination of air travel service attributes with its conditional indirect utility level $\mathrm{V} j$ for individual $i$. Therefore, the utility function is as shown below:

$\mathrm{V} i j=v i j+\varepsilon i j$

Equation 1 considers $v i j$ as the deterministic component and $\varepsilon i j$ as the random component. According to Casey, Kahn and Rivas (2008) "If the individual is observed choosing alternative $j$ over alternative $h$ it is implied that the utility of Vij is greater than that of Vih" (Casey et al., 2008, p. 556). Accordingly, probability of an individual $i$ choosing alternative $j$, is as displayed below:

$p(i j / c)=\mathrm{p}[\mathrm{V} i j>\mathrm{V} i h]=p[(v i j+\varepsilon i j)>(v i h+\varepsilon i h)], j \neq h$

Based on the abovementioned equation, assuming the utility function's error terms to be independently and identically distributed, it seems plausible to estimate the utility function with the MNL model (Casey et al., 2008; McFadden, 1974; Shrestha and Alavalapati, 2004). The MNL model is represented as follow:

$p(i j)=\exp u v i j / \sum_{i j \in c} \exp u v i j$

According to Louviere et al. (2000), assuming $u$ as the scale parameter normalized to one and vij linear and additive in the attributes, the utility function would be as follow: $\mathrm{V} i j=v(\beta+\beta 1 \mathrm{Z} 1+\beta 2 \mathrm{Z} 2+\ldots+\beta n \mathrm{Zn}+\beta a \mathrm{~S} 1+\beta \mathrm{bS} 2+\ldots+\beta m \mathrm{~S} k)$

As illustrated in equation $5, \beta$ is the constant term and $\beta 1$ though $\beta n$ are vectors of coefficients attached to choice set attributes ( $\mathrm{Z} 1$ through $\mathrm{Zn})$ and $\beta a$ through $\beta m$ represent coefficients associated with respondents' socio-economic characteristics ( $\mathrm{S} 1$ through $\mathrm{Sm}$ ) which are assumed to influence respondents' utility (Gilbert and Wong, 2003).

The present study investigated the respondent's WTA low-cost air travel services, which represents the compensating surplus for a decrease in air travel services offered by an airline. "Compensating surplus (CS) is the amount of money that must be given or taken away from a person to make him or her as well off after a change as they were before a change. If the change leaves the person worse off, then CS is equivalent to willingness to accept (WTA)". (Casey et al., 2000, P. 556). Thus, marginal value of a change within a specific attribute would be represented as coefficients' ratio:

$\mathrm{W}=-1(\beta a / \beta c)$

Where $\beta a$ represents non-monetary attributes' coefficient and $\beta c$ represents monetary attributes' coefficient. Using equation 5 , this study estimates marginal rate of substitution between associated changes in ticket fare and the other air transport service attributes as manifested by ticket fare, flexibility, frequency, punctuality, FFP, F\&B services and ground services. According to Grutters et al. (2008), the possibility to understand the trade-offs among study attributes have made discrete choice models an appealing method of evaluation.

\subsection{Survey design and implementation}

Travel demand can be modeled based on respondents' stated preferences (Grigolon et al., 2012; Hensher, 1994; Hess et al., 2007; Kroes and Sheldon, 1988; Louviere, 1988). In so doing, respondents are asked to express their preferences based on a set of theoretical choice situations (designed alternatives). "Stated Preference (SP) 
techniques have the advantage that the analyst can carefully design the choice tasks and thereby allow for a design that enables a relatively straightforward identification of effects". (Van Cranenburgh et al., 2014, p.107). This approach is particularly valid in explaining airline choice behavior (Hess et al., 2007). Based on the underlying assumptions provided by Lancaster's value theory (1966) and Thurstone's random theory (1927), this study investigates respondents' preferences regarding their choice of air transport services. To do so, a thorough review of relative literature followed by experts' opinion regarding viability and reliability of attributes and their associated levels, resulted in identification of attributes applicable to air transport choice. Accordingly, a careful definition of attribute levels has been adjusted. Careful definition of attributes and their levels would enhance the realism of experiment (Hensher, Rose and Greene, 2005). Finally, attribute levels should be combined together to form a number of useful choice scenarios.

For the current study, a comprehensive review of relative literature concerning determining factors (i.e. attributes) affecting LCCs choice revealed that ticket fare, flexibility, frequency, punctuality, FFP, F\&B services as well as ground services are among important attributes.

According to Balcombe, Fraser and Harris (2009, p.221) "because the LCC business model is based on maximizing utilization of aircraft (two return journeys per day); to keep them in the air for the longest possible time, flight range is limited to $3 \mathrm{hs".}$ Accordingly, the present study, assumes that ticket fare corresponds to the total fare paid by passengers for a one way trip for flights below $3 \mathrm{hs}$. While flexibility refers to the opportunity given to passengers to book a flight or make changes to their flights freely, frequency denotes a number of flights presented in the flight schedule for a specific destination per day. Punctuality, in addition, is associated with the accuracy of takeoffs which would result in a more accurate schedule planning. As the other important attribute for air transport service, FFP refers to the opportunity given to passengers to collect bounces for their miles flown by a particular airline. F\&B services are associated with the food and beverages available on board the aircraft, on the other hand, ground services refer to additional services provided by airlines on the ground such as baggage handling and express check-in. The configuration of air transport service attributes represented above is in line with previous research in the air transport literature (e.g. Teichert, Shehu and von Wartburg, 2008).

Each attribute involves 2 levels for this study generating 128 scenarios $\left(2^{7}=128\right)$. Even though a full factorial design would result in orthogonality, unmanageable numbers of possible scenarios reduces the quality of experiment (Yoo and Ashford, 1996). Moreover, it is assumed that too difficult or too long experimental tasks affects the quality of data collection (Carson et al., 1994). Therefore, as demonstrated in table 1, common attribute technique has been used to reduce the number of ultimate scenarios (Hensher, 1994; Kores and Sheldon, 1998). Consequently, ticket fare has been selected as the common attribute, assuming that LCCs share the "cult of cost reduction" (Lawton, 2003, p. 175) and target low-margin consumers (Grigolon et al., 2012; O'Connell and Williams, 2005). In addition, review of extant literature revealed that ticket fare plays an important role in choosing an airline (e.g. Jung and Yoo, 2014; Milioti et al., 2015; Yoo and Ashford, 1996). 
Table1 Air transport service attributes and levels in CE

\begin{tabular}{|c|c|c|}
\hline & Attributes & levels \\
\hline \multirow[t]{8}{*}{ CE1 } & Ticket fare & Normal \\
\hline & & Up to $50 \%$ discount \\
\hline & FFP & Not available \\
\hline & & Available \\
\hline & F\&B services & Not free \\
\hline & & Free \\
\hline & Ground services & Not free \\
\hline & & Free \\
\hline \multirow[t]{8}{*}{$\overline{\text { CE2 }}$} & Ticket fare & Normal \\
\hline & & Up to $50 \%$ discount \\
\hline & Flexibility & Changing ticket with penalty \\
\hline & & Changing ticket without penalty \\
\hline & Punctuality & Sometimes with delay \\
\hline & & Always on-time \\
\hline & Frequency & One flight per day \\
\hline & & More than one flight per day \\
\hline
\end{tabular}

Source: own

In order to analyze respondents' choice, a detailed questionnaire was designed. The first part of the questionnaire contains information regarding the aims of the research and confidentiality of responses received during data collection. The second part is associated with respondents' travel behavior while the third part deals with the choice experiment. This part, starts with a detailed explanation of attributes and their associated levels to enhance the quality of responses. A random selection of choice sets was presented to respondents and they were asked to answer 7 choice sets in both CE1 and CE2. According to Holmes and Adamowicz (2003), use of random distribution of choice sets in CE is a proper strategy for large samples. Responses to this part are further used to measure the value respondents place on flight service characteristics. An example of choice cart is presented in figure 1. Cards included various explanatory notes to improve response quality.

Figure 1 Sample choice cart

\begin{tabular}{|c|c|c|c|c|}
\hline Altribute & Ticket fare & Frequent flyer program & F\&B services & Ground services \\
\hline A & $23 \$$ & Available & Free & Not free \\
\hline $\mathrm{B}$ & $45 \$$ & Not available & Free & Free \\
\hline
\end{tabular}

Your choice:

A

B

Don't know

Source: own

In addition, 2 scenarios were entered in each choice card with three options to choose. Specifically, a "don't know" option was added as this option "allows the respondents to provide an answer that does not force an inappropriate choice. Thus, it enables the elicitation of a more realistic view of the respondent's true preferences" (Balcombe et al., 2008, p.223). The "don't know" responses were, however, regarded as zero choice and were not entered in estimation. The last part of the questionnaire 
ultimately entails information regarding respondents' socio-economic characteristics. The survey instrument has been delivered face to face to respondents. Mehr-Abad airport has been chosen as the main place for data collection since this airport is the hub airport for domestic flights in Iran. In terms of survey delivery, face to face interview was combined with the questionnaire representation. Respondents were informed about the academic purpose of the data collection process and ensured about the confidentiality of the responses. A total number of 150 questionnaires were distributed among passengers in all Mehr-Abad departure terminals using a convenient sampling procedure. One hundred and twenty-seven useable questionnaires were returned. Table 2 represents the features of survey campaign.

Table 2 Features of survey campaign

\begin{tabular}{ll}
\hline Airport & Mehr-Abad airport; departure lounges \\
Data collection method & Questionnaire \\
Sampling procedure & Sample size: 127 \\
& Number of observations: 1778 \\
Field work & Sampling method: convenient sampling \\
\hline
\end{tabular}

Source: own

\section{Results}

\subsection{Demographic characteristics}

According to the results, half of the respondents are aged below 35 years, while $27.6 \%$ are aged between 36 and 45, 8.7\% are aged between 46 and 55 and the rest are older than 56. More than half of respondents are male $(71.7 \%)$ and married $(56.7 \%)$. Respondents' educational level is spread across all ranges where $1.6 \%$ of respondents had primary school education, $3.9 \%$ had diploma, $15.7 \%$ had higher diploma, $47.2 \%$ had bachelor degree and $31.5 \%$ had master or $\mathrm{PhD}$. In addition, more than half of the respondent $(58.2 \%)$ indicated their monthly income below $667 \$$, while $22 \%$ indicated monthly income between $667 \$$ and $1100 \$$ and the rest $19.6 \%$ indicated monthly income more than $1100 \$$. Respondents were also asked regarding their job positions. According to their response, $37 \%$ are private business owner, while $18.9 \%$ are governmental employees and the rest are contract employees. A detailed information regarding passengers' socio-economic characteristics are provided in table 3.

Table 3 Respondents' socio-economic profile

\begin{tabular}{clll}
\hline Age & Frequency & Percentage \\
$18-25$ & 28 & 22 \\
$26-35$ & 49 & 38.6 \\
$36-45$ & 35 & 27.6 \\
$46-55$ & 11 & 8.7 \\
$56-65$ & 4 & 3.1 \\
Total & 127 & 100 \\
\hline Gender & Frequency & Percentage \\
Female & 36 & 28.3 \\
Male & 91 & 71.7
\end{tabular}




\begin{tabular}{cll} 
Total & 127 & 100 \\
\hline Marital status & Frequency & Percentage \\
Single/divorced & 55 & 43.3 \\
Married & 72 & 56.7 \\
Total & 127 & 100 \\
\hline Education & Frequency & Percentage \\
Primary school & 2 & 1.6 \\
Diploma & 5 & 3.9 \\
Higher diploma & 20 & 15.7 \\
Bachelor & 60 & 47.2 \\
Master or PhD & 40 & 31.5 \\
Total & 127 & 100 \\
\hline Job position & Frequency & Percentage \\
Private business owner & 47 & 37 \\
Governmental Employee & 24 & 18.9 \\
Contract Employee & 56 & 44.1 \\
Total & 127 & 100 \\
\hline Monthly income & Frequency & Percentage \\
Up to $230 \$$ & 21 & 16.5 \\
230\$-667\$ & 53 & 41.7 \\
667\$-1100\$ & 28 & 22 \\
$1100 \$-1600 \$$ & 12 & 9.4 \\
More than $1600 \$$ & 13 & 10.2 \\
Total & 127 & 100 \\
\hline
\end{tabular}

Source: own

\subsection{Travel characteristics}

Respondents were asked regarding their travel characteristics. Respondents took an average of 17 trips during last 2 years. The most common reason for travel was business $(70.1 \%)$. Most of the respondents were traveling with family as their trip partner $(41.7 \%)$ and more than a half were attracted to leisure attractions $(70.1 \%)$. Most of the respondents indicated that they would by their tickets from travel agencies $(53.5 \%)$. Majority of respondents neither heard about LCCs (69.3\%) nor had a previous flight experience with LCCs (53.5\%) (See table 4).

Table 4 Respondents' travel characteristics

\begin{tabular}{|c|c|c|}
\hline Flight purpose & Frequency & Percentage \\
\hline Business & 89 & 70.1 \\
\hline Leisure & 38 & 29.9 \\
\hline Total & 127 & 100 \\
\hline Travel partner & Frequency & Percentage \\
\hline Family & 53 & 41.7 \\
\hline Friends & 31 & 24.4 \\
\hline Colleagues & 38 & 29.9 \\
\hline Others & 5 & 3.9 \\
\hline Total & 127 & 100 \\
\hline Type of destination attractiveness & Frequency & Percentage \\
\hline
\end{tabular}




\begin{tabular}{cll} 
Leisure and recreation & 89 & 70.1 \\
Health tourism & 3 & 2.4 \\
Heritage tourism & 28 & 22 \\
Pilgrimage & 7 & 5.5 \\
Total & 127 & 100 \\
\hline Ticket buying method & Frequency & Percentage \\
Travel agency & 68 & 53.5 \\
Websites & 51 & 40.2 \\
Airlines' ticket center & 8 & 6.3 \\
Total & 127 & 100 \\
\hline Familiar with LCCs & Frequency & Percentage \\
Yes & 39 & 30.7 \\
No & 88 & 69.3 \\
Total & 127 & 100 \\
\hline Flight experience with LCCs & Frequency & Percentage \\
Yes & 68 & 53.5 \\
No & 59 & 46.5 \\
Total & 127 & 100 \\
\hline
\end{tabular}

Source: own

\subsection{The MNL model results}

The calculation of WTA in discrete choice models can be performed with the inclusion of cost attribute (Grutters et al., 2008). Accordingly, this study uses ticket fare as the common attribute which is used in both CE1 and CE2. For both types of choice sets, a separate logit model has been calibrated. As shown in table 5, for the CE1 including FFP, F\&B services and ground services, negative sign on aforementioned attributes indicates that respondents are willing to lose ground services $(\beta=-0.55, p<0.01)$, followed by F\&B services $(\beta=-0.56, p<0.01)$ and FFP $(\beta=-0.94, p<0.001)$ if the airline offers $50 \%$ discount on its ticket fare $(\beta=0.01, p<0.001)$. Particularly, respondents are willing to accept the loss of FFP only with the associated reduction in ticket fare i.e. $21 \$$. Respondents further indicated their willingness to accept the loss of F\&B services with a particular reduction in ticket fare i.e. $11 \$$ and the loss of ground services with a specific reduction in ticket fare i.e. $10 \$$.

In addition, this study used frequency, flexibility and punctuality attributes to test respondents' willingness to accept the loss of those attributes while choosing an airline that offers a $50 \%$ discount on its ticket fare $(\beta=-0.01, p<0.001)$. As the results of MNL model negative sing on frequency, flexibility and punctuality attributes displays respondents' willing to loose flights frequency $(\beta=-0.62, p<0.001)$ followed by flight flexibility $(\beta=-0.70, p<0.001)$ and punctuality of the flights $(\beta=-0.97, p<0.001)$. Particularly respondents are willing to accept the loss of flexibility in buying ticket if the designated airline reduce $40 \$$ of its ticket fare. Moreover, respondents indicated their willingness to accept the loss of flight punctuality with a specific reduction in ticket i.e. $24 \$$ and flight frequency with an associated reduction in ticket fare i.e. $15 \$$.

Table 5 Results of MNL model

\begin{tabular}{llllll}
\hline$C E 1^{a}$ & Coefficient & $\mathrm{CS}^{c}$ & $C E 2^{b}$ & Coefficient & $\mathrm{CS}^{c}$ \\
Ticket fare & $0.0122381^{*}$ & - & Ticket fare & $0.0094569^{*}$ & -
\end{tabular}


F\&B services $-0.5690791 * *$

Ground services $-0.5571085^{* *}$ $(-3.14)$

$11 \$$

$10 \$$

$\begin{array}{lll}\text { Flexibility } & -0.7043704 * 17 \$ \\ & (-4.04) \\ \text { Punctuality } & -0.9750908 * 23 \$ \\ & (-7.38) \\ \text { Frequency } & -0.6261917 * 15 \$ \\ & (-3.48) \\ \end{array}$

Source: own

${ }^{*} p<0.001 ; * * p<0.01 ;{ }^{a}$ Log likelihood $=-698.03116$; Pseudo $\mathrm{R} 2=0.0535 ;{ }^{b}$ Log likelihood $=-$ 700.81399; Pseudo R2 = 0.0444; ${ }^{c}$ Compensating surplus.

The socio-economic characteristics of the respondents are included in the analysis. According to the results, the socio-economic characteristics would only affect various WTAs for specific groups. For instance, the WTA the loss of FFP $(\beta=-1.29 ; p=0.6)$, $\mathrm{F} \& \mathrm{~B}$ services $(\beta=-0.25 ; p=0.64)$ and ground services $(\beta=-0.03 ; p=0.95)$ is not statistically significant for the respondents aged more than 46 years. This is also the case for the WTA the loss of flexibility $(\beta=-0.42 ; p=0.66)$, punctuality $(\beta=-1.52 ; \mathrm{p}=0.16)$ and frequency $(\beta=-0.40 ; p=0.67)$ for the respondents who are aged more than 56 years. It appears that the older the respondents, the more they are demanding additional services. These findings are in line with Grigolon et al. (2012), who claim LCCs are appealing for young markets. In addition, results revealed that male respondents' WTA the loss of F\&B services $(\beta=-0.18 ; p=0.39)$ and ground services $(\beta=-0.25 ; p=0.23)$ is not significant. That is, male respondents are willing to be served by free F\&B services on board the aircraft as well as receiving ground services including express check in and baggage handling. In line with our expectations, as respondents are earning more on a monthly basis, their WTA the loss of services will be lower. According to the results, WTA the loss of FFP $(\beta=-0.88 ; p=0.07), \mathrm{F} \& \mathrm{~B}$ services $(\beta=-0.49 ; p=0.35)$ and ground services ($0.17 ; p=0.73)$ as well as the WTA the loss of flexibility $(\beta=-0.44 ; p=0.66)$, punctuality $(\beta=-1.52 ; p=0.16)$ and frequency $(\beta=0.40 ; p=0.67)$ is not statistically significant for the respondents who earn more than 5,000,000t per month. Scholars echoed the price sensitivity of LCCs' passengers and assert that lower income markets are more attracted to air transport services provided by LCCs (e.g., Castillo-Manzano et al., 2011; MartínezGarcia and Raya, 2008; Milioti et al., 2015). The Results further revealed that highly educated respondents' WTA the loss of flexibility $(\beta=-0.50 ; p=0.12)$, and contract employees' WTA the loss of ground services $(\beta=-0.41 ; p=0.10)$ are not significant. It is assumed that highly educated respondents place more importance to their right for the flexibility in buying an air ticket.

Further analysis revealed that the significance of coefficients associated with air transport service attributes varies across different levels of travel characteristics. Particularly, non-business travelers are putting more emphasis on the availability of FFP $(\beta=-0.94 ; p<0.001), \mathrm{F} \& \mathrm{~B}$ services $(\beta=-0.56 ; p<0.01)$ and ground services $(\beta=-0.55$; $p<0.01)$, while, three other attributes in terms of flexibility $(\beta=-0.72 ; \mathrm{p}<0.01)$, punctuality $(\beta=-1.43 ; p<0.01)$ and frequency $(\beta=-0.70 ; p=0.01)$ are shown to be more important for business travelers. That is, business travelers display more concern about the loss of air transport service attributes in terms of flexibility, punctuality and frequency. In addition, availability of FFP $(\beta=-.91 ; p<0.01)$ and flight flexibility $(\beta=-0.73 ; p<0.01)$ appears to be of a greater concern for those who travel with their colleagues. This is the also the case for respondents who are primarily attracted to holly tourism attractions with a significant coefficient $(\beta=-0.70)$ for the availability of FFP and a significant coefficient $(\beta=-0.63)$ for flight flexibility. The distinction in the significance of air transport service 
attributes slightly differs in the way that respondents buy their tickets. Particularly, the association between ticket fare, frequency, punctuality and frequency and respondents' choice of an airline is not significant for those who obtain their tickets from the airline ticket center. This may be the reason for the fact that passengers who obtain their tickets directly from the airline are assured regrading frequency, punctuality and frequency of the flights offered by that specific airline. Respondents who had previous familiarity with LCCs expressed more importance on the availability of ground services $(\beta=-1.01$; $p<0.01)$ while those who were not familiar with LCCs put more emphasis on flight punctuality $(\beta=-1.49 ; p<0.001)$. It appears that passengers who previously flow with a LCC experienced difficulties with unavailability of ground services. In addition, it seems that passengers who are not familiar with services provided by LCCs believe that LCCs are less reliable in terms of flight punctuality. This variation is also observed for respondents with previous flight experience with LCCs with a significant coefficient for flight flexibility $(\beta=-0.81 ; p<0.001)$ and the availability of ground services $(\beta=-0.68$; $p<0.05)$. Results further demonstrates that there is no consistent pattern in the importance of air transport service attribute across different levels of minimum discount accepted by respondents. For example, respondents who accept minimum level of discount equal to $20 \%-40 \%$ put more emphasis on the availability of FFP $(\beta=-1.30 ; p<0.01)$ than other respondents with different accepted levels of minimum discount on ticket fare. In addition, respondents displayed a great concern on punctuality $(\beta=-1.35 ; p<0.01)$ while requesting for at least $60 \%-80 \%$ discount on ticket fare. This is also reconcilable for maximum no-frills flight time tolerated by respondents. Specifically, respondents who were not concerned about the maximum no-frills flight time, exhibited more attention to flight punctuality $(\beta=-1.36 ; p<0.001)$ and respondents who were more concerned about the availability of FFP $(\beta=-1.03$; $p<0.001)$ only tolerated no-frills flight with a maximum of 1-2hs flight time.

\section{Discussion}

A number of handful solutions are associated with the emergence of LCCs such as demand development from existing passengers as well as new demand stimulation from potential users who could not afford air travel ticket fare (Castillo-Manzano et al., 2011). Against this realization, however, majority of operating airlines in developing economies are clung to traditional full service business model and a few number of LCCs has penetrated to this market environment as the knowledge of LCCs and the associated success factors to attract more demand for low-cost air transport services are still in its infancy. Accordingly, several CEs has been deployed to examine WTA low-cost air transport services. The results indicate that service re-design is a viable strategy to deal with the fragmented air transport market for flights below 3 hs flight range. In addition, air transport service attributes in terms of ticket fare, FFP, F\&B services, ground services, flexibility, frequency and punctuality are demonstrated to be valued by air transport consumers and enable various WTAs for specific levels of aforementioned attributes as well as associated socio-economic characteristics and travel behavior of respondents. Particularly, the WTA the loss of such attributes is associated with a specific reduction in ticket fare equal to $21 \$, 10 \$, 10 \$, 42 \$, 24 \$$ and $15 \$$, respectively. Probably, the significant contribution of the current study lies in the elaboration of the important role played by flight punctuality above and beyond other determining factors associated with passengers' choice of LCCs. Hence, it seems plausible for airline managers and potential 
investors to keep a close eye on developing infrastructure facilitating flight punctuality. In addition, it is suggested that actual and potential actors in air transport market consider service re-design and the magnitude of service offerings above and beyond existing approaches adopted by full service carriers. Indeed, the WTA values estimated in this study shed light on the opportunity to revise air transport service provision in terms of reduced FFP, F\&B services, ground services, flexibility, frequency and punctuality while proposing lower ticket fare to younger and lower income markets.

\subsection{Practical implications}

The results of the current study provide handful guidelines for airline managers and prospective practitioners in designing low-cost air transport services for the markets where such services are not offered. Specifically, there is a call for managers' and policy makers' attention pertaining to the importance of actual and potential market's sociodemographic characteristics. That is, low-cost air transport services must be welldesigned for the younger generation with more digital presence as the young generation is highly enchanted with digital platforms. Targeting different types of markets in terms of their income levels is also a place for practical concern as population with higher income are willing to pay more to get additional services, while their counterparts with lower income levels have shown more propensity to accept low-cost air transport services. Moreover, the provision of low-cost air transport services may be more attractive for female, hence, it seems plausible to put marketing and advertising efforts based on female characteristics. In addition to above-mentioned characteristics, respondents varied based on their travel behavior. The significant difference in respondents' preferences were observed in relation with their travel purpose, as business travelers were concerned about the flight characteristics. Accordingly, low-cost air transport services may be best designed to deliver punctual, frequent flights with flexibility in reservations to assure business traveler are attracted. Above and beyond aforementioned considerations, attracting actual and potential market to patronize low-cost air transport services is well associated with their familiarity with the services provided by such carriers. That is, passengers who willingly choose LCCs to fly with, have a previous flight experience (Chang and Sun, 2012; Mason, 2001). This would endorse the importance of informative marketing activities promoting low-cost air transport services. According to the findings, it is also apparent that the provision of FFP matters for almost all type of travel behavior. Hence, provision of FFP as a neglected service offered by a considerable number of LCCs would act as a competitive advantage as well as a value added to the existing services.

\subsection{Limitations and further research}

Like many similar empirical studies, this study faced several limitations which may open doors for future research efforts. First, this study used a single analytical approach to assess respondents' preferences regarding LCCs' services. Existing data may be also used to assess other types of logit models in terms of conditional and nested models to evaluate interactions among study attributes. In order to provide more insight, therefore, further research may calibrate different types of logit models to compare the results of the survey. Second, this study addressed passengers' preferences and their WTA low-cost air transport services using choice experiment. However, to better understand 
and validate the significance of attributes used in the survey, it may be appropriate to use top 3 to 5 attributes as predictive variable in a structural equation model to investigate its causal impact on passengers' attitudes and actual behavior regarding their choice of LCCs. Third, this study conducted survey in Iran as a developing middle eastern country, as this region suffers from the lack of empirical and academic research pertaining to the feasibility of low-cost air transport services. However, this single cultural and socioeconomic environment may raise the issue of generalizability. In order to broaden the knowledge based regarding the aims of the current study, hence, the use of cross-cultural as well as the choice of other countries with different socio-economic demography would be highly recommended.

\subsection{Conclusion}

This study shed light on the importance and feasibility of low cost air transport services in Iran, a developing country in which such services are yet unavailable. Particularly, passengers' preferences are shown to be affected by ticket fare, F\&B services, FFP, ground services, punctuality, frequency and flexibility of flights offered by LLCs with varying impacts across different socio-demographic levels and travel behavior of prospective consumers. Conferring to the importance of LLC in developing demand (Augustyniak, 2014; Kalinowski, 2014). as well as its contribution to economic growth and market competitiveness (Stichhauerova and Pelloneova, 2019), airline managers and macro policy makers in any given region are encouraged to provide opportunities for the development of such services.

\section{References}

1. Adeola, M. M., \& Adebiyi, S. O. (2014). Service quality, perceived value and customer satisfaction as determinant of airline choice in Nigeria. International Letters of Social and Humanistic Sciences, 20, 66-80.

2. Akamavi, R. K., Mohamed, E., Pellmann, K., \& Xu, Y. (2015). Key determinants of passenger loyalty in the low-cost airline business. Tourism management, 46 , 528-545.

3. Alamdari, F. E., \& Black, I. G. (1992). Passengers' choice of airline under competition: the use of the logit model. Transport Reviews, 12(2), 153-170.

4. Augustyniak, W. (2014). Efficiency change in regional airports during market liberalization. Economics \& Sociology, 7(1), 85.

5. Balcombe, K., Fraser, I., \& Harris, L. (2009). Consumer willingness to pay for inflight service and comfort levels: A choice experiment. Journal of Air Transport Management, 15(5), 221-226.

6. Basu, D., \& Hunt, J. D. (2012). Valuing of attributes influencing the attractiveness of suburban train service in Mumbai city: A stated preference approach. Transportation Research Part A: Policy and Practice, 46(9), 14651476.

7. Ben-Akiva, M. E., Lerman, S. R., \& Lerman, S. R. (1985). Discrete choice analysis: theory and application to travel demand (Vol. 9). MIT press. 
8. Brons, M., Pels, E., Nijkamp, P., \& Rietveld, P. (2002). Price elasticities of demand for passenger air travel: a meta-analysis. Journal of Air Transport Management, 8(3), 165-175.

9. Carson, R. T., Louviere, J. J., Anderson, D. A., Arabie, P., Bunch, D. S., Hensher, D. A., ... \& Timmermans, H. (1994). Experimental analysis of choice. Marketing letters, 5(4), 351-367.

10. Cirillo, C., \& Axhausen, K. W. (2006). Evidence on the distribution of values of travel time savings from a six-week diary. Transportation Research Part A: Policy and Practice, 40(5), 444-457.

11. Casey, M. E. (2010). Low cost air travel: Welcome aboard?. Tourist Studies, 10(2), 175-191.

12. Casey, J. F., Kahn, J. R., \& Rivas, A. A. (2008). Willingness to accept compensation for the environmental risks of oil transport on the Amazon: a choice modeling experiment. Ecological Economics, 67(4), 552-559.

13. Castillo-Manzano, J. I., López-Valpuesta, L., \& González-Laxe, F. (2011). The effects of the LCC boom on the urban tourism fabric: The viewpoint of tourism managers. Tourism Management, 32(5), 1085-1095.

14. Chang, L. Y., \& Sun, P. Y. (2012). Stated-choice analysis of willingness to pay for low cost carrier services. Journal of Air Transport Management, 20, 15-17.

15. Chen, H. T., \& Chao, C. C. (2015). Airline choice by passengers from Taiwan and China: A case study of outgoing passengers from Kaohsiung International Airport. Journal of Air Transport Management, 49, 53-63.

16. Chen, C. F., \& Wu, T. F. (2009). Exploring passenger preferences in airline service attributes: A note. Journal of Air Transport Management, 15(1), 52-53.

17. Davidson, J. P. (1990). Marketing your consulting and professional services. New York: Wiley.

18. Dennet't, C., Ineson, E. M., Stone, G. J., \& Colgate, M. (2000). Pre-bookable services in the chartered airline industry: Increasing satisfaction through differentiation. The Service Industries Journal, 20(2), 82-94.

19. Dobruszkes, F. (2006). An analysis of European low-cost airlines and their networks. Journal of Transport Geography, 14(4), 249-264.

20. Escobari, D. (2017). Airport, airline and departure time choice and substitution patterns: An empirical analysis. Transportation Research Part A: Policy and Practice, 103, 198-210.

21. Espino, R., Martín, J. C., \& Román, C. (2008). Analyzing the effect of preference heterogeneity on willingness to pay for improving service quality in an airline choice context. Transportation Research Part E: Logistics and Transportation Review, 44(4), 593-606.

22. Fleischer, A., Peleg, G., \& Byk, J. R. (2011). The impact of changes in household vacation expenditures on the travel and hospitality industries. Tourism Management, 32(4), 815-821.

23. Fleischer, A., Tchetchik, A., \& Toledo, T. (2015). Does it pay to reveal safety information? The effect of safety information on flight choice. Transportation Research Part C: Emerging Technologies, 56, 210-220.

24. Francis, G., Dennis, N., Ison, S., \& Humphreys, I. (2007). The transferability of the low-cost model to long-haul airline operations. Tourism management, 28(2), 391-398.

25. Gilbert, D., \& Wong, R. K. (2003). Passenger expectations and airline services: a Hong Kong based study. Tourism Management, 24(5), 519-532. 
26. Graham, B., \& Shaw, J. (2008). Low-cost airlines in Europe: Reconciling liberalization and sustainability. Geoforum, 39(3), 1439-1451.

27. Govindarajan, V., \& Kopalle, P. K. (2006). The usefulness of measuring disruptiveness of innovations ex post in making ex ante predictions. Journal of product innovation management, 23(1), 12-18.

28. Grigolon, A. B., Kemperman, A. D., \& Timmermans, H. J. (2012). The influence of low-fare airlines on vacation choices of students: Results of a stated portfolio choice experiment. Tourism Management, 33(5), 1174-1184.

29. Grutters, J. P., Kessels, A. G., Dirksen, C. D., Van Helvoort-Postulart, D., Anteunis, L. J., \& Joore, M. A. (2008). Willingness to accept versus willingness to pay in a discrete choice experiment. Value in Health, 11(7), 1110-1119.

30. Hagmann, C., Semeijn, J., \& Vellenga, D. B. (2015). Exploring the green image of airlines: Passenger perceptions and airline choice. Journal of Air Transport Management, 43, 37-45.

31. Han, H. (2013). Effects of in-flight ambience and space/function on air travelers' decision to select a low-cost airline. Tourism management, 37, 125-135.

32. Hensher, D. A. (1994). Stated preference analysis of travel choices: the state of practice. Transportation, 21(2), 107-133.

33. Hensher, D.A., Rose, J.M. \& Greene, W.H. (2005). Applied choice analysis: a primer. Cambridge University Press.

34. Hensher, D. A. (2001). The sensitivity of the valuation of travel time savings to the specification of unobserved effects. Transportation Research Part E: Logistics and Transportation Review, 37(2-3), 129-142.

35. Hess, S. (2008). Treatment of reference alternatives in stated choice surveys for air travel choice behaviour. Journal of Air Transport Management, 14(5), 275279.

36. Hess, S., Adler, T., \& Polak, J. W. (2007). Modelling airport and airline choice behaviour with the use of stated preference survey data. Transportation Research Part E: Logistics and Transportation Review, 43(3), 221-233.

37. Hess, S., \& Polak, J. W. (2006). Airport, airline and access mode choice in the San Francisco Bay area. Papers in Regional Science, 85(4), 543-567.

38. Holmes, T. P., \& Adamowicz, W. L. (2003). Attribute-based methods. In 'A Primer on Nonmarket Valuation'.(Eds P. Champ, KJ Boyle and TC Brown.) pp. 171-219.

39. Jara-Díaz, S. R., \& Guevara, C. A. (2003). Behind the subjective value of travel time savings. Journal of Transport Economics and Policy (JTEP), 37(1), 29-46.

40. Jeng, S. P. (2016). The influences of airline brand credibility on consumer purchase intentions. Journal of Air Transport Management, 55, 1-8.

41. Jiang, H., \& Zhang, Y. (2016). An investigation of service quality, customer satisfaction and loyalty in China's airline market. Journal of air transport management, 57, 80-88.

42. Jung, S.Y. and Yoo, K.E. (2014), "Passenger airline choice behavior for domestic short-haul travel in South Korea." Journal of Air Transport Management, Vol. 38, pp. 43-47.

43. Jung, J., Han, H., \& Oh, M. (2017). Travelers' switching behavior in the airline industry from the perspective of the push-pull-mooring framework. Tourism Management, 59, 139-153.

44. Kalinowski, S. (2014). Impact of Investment Activity on European Regional Airports Performance. Economics \& Sociology, 7(3), 40. 
45. Kroes, E. P., \& Sheldon, R. J. (1988). Stated preference methods: an introduction. Journal of transport economics and policy, 11-25.

46. Koo, T. T., Caponecchia, C., \& Williamson, A. (2018). How important is safety in making flight choices? Evidence from simple choice experiments. Transportation, 45(1), 159-175.

47. Kumar, N. (2006). Strategies to fight low-cost rivals. Harvard Business Review, 84(12), 104.

48. Kurtulmuşoğlu, F. B., Can, G. F., \& Tolon, M. (2016). A voice in the skies: Listening to airline passenger preferences. Journal of Air Transport Management, 57, 130-137.

49. Lancaster, K. J. (1966). A new approach to consumer theory. Journal of political economy, 74(2), 132-157.

50. Lawton, T. C. (2003). Managing proactively in turbulent times: Insights from the low-fare airline business. Irish Journal of Management, 24(1), 173.

51. Lhéritier, A., Bocamazo, M., Delahaye, T., \& Acuna-Agost, R. (2018). Airline itinerary choice modeling using machine learning. Journal of Choice Modelling.

52. Lloyd-Smith, P., \& Adamowicz, W. (2018). Can stated measures of willingnessto-accept be valid? Evidence from laboratory experiments. Journal of Environmental Economics and Management, 91, 133-149.

53. Louviere, J. J. (1988). Conjoint analysis modelling of stated preferences. Journal of transport economics and policy, 22(1), 93-119.

54. Louviere, J. J., Hensher, D. A., \& Swait, J. D. (2000). Stated choice methods: analysis and applications. Cambridge university press.

55. Luce, R. D. (2012). Individual choice behavior: A theoretical analysis. Courier Corporation.

56. Marcus, B., \& Anderson, C. K. (2008). Revenue management for low-cost providers. European Journal of Operational Research, 188(1), 258-272.

57. Martinez-Garcia, E., \& Raya, J. M. (2008). Length of stay for low-cost tourism. Tourism management, 29(6), 1064-1075.

58. Mason, K. J. (2001). Marketing low-cost airline services to business travellers. Journal of Air Transport Management, 7(2), 103-109.

59. Mason, K. J., \& Alamdari, F. (2007). EU network carriers, low cost carriers and consumer behaviour: A Delphi study of future trends. Journal of Air Transport Management, 13(5), 299-310.

60. McFadden, D. (1974). Analysis of Qualitative Choice Behavior. Zarembka, P.(ed.): Frontiers in Econometrics.

61. Medina-Muñoz, D. R., Medina-Muñoz, R. D., \& Suárez-Cabrera, M. Á. (2018). Determining important attributes for assessing the attractiveness of airlines. Journal of Air Transport Management, 70, 45-56.

62. Milioti, C. P., Karlaftis, M. G., \& Akkogiounoglou, E. (2015). Traveler perceptions and airline choice: A multivariate probit approach. Journal of Air Transport Management, 49, 46-52.

63. O'Connell, J. F., \& Williams, G. (2005). Passengers' perceptions of low cost airlines and full service carriers: A case study involving Ryanair, Aer Lingus, Air Asia and Malaysia Airlines. Journal of Air Transport Management, 11(4), 259272.

64. O'Connell, J. F., \& Warnock-Smith, D. (2013). An investigation into traveler preferences and acceptance levels of airline ancillary revenues. Journal of Air Transport Management, 33, 12-21. 
65. Ong, W. L., \& Tan, A. K. (2010). A note on the determinants of airline choice: The case of Air Asia and Malaysia Airlines. Journal of Air Transport Management, 16(4), 209-212.

66. Park, J. W. (2007). Passenger perceptions of service quality: Korean and Australian case studies. Journal of Air Transport Management, 13(4), 238-242.

67. Rajaguru, R. (2016). Role of value for money and service quality on behavioural intention: A study of full service and low cost airlines. Journal of Air Transport Management, 53, 114-122.

68. Pels, E., Nijkamp, P., \& Rietveld, P. (2003). Access to and competition between airports: a case study for the San Francisco Bay area. Transportation Research Part A: Policy and Practice, 37(1), 71-83.

69. Rose, J. M., Hensher, D. A., \& Greene, W. H. (2005). Recovering costs through price and service differentiation: accounting for exogenous information on attribute processing strategies in airline choice. Journal of Air Transport Management, 11(6), 400-407.

70. Rouncivell, A., Timmis, A. J., \& Ison, S. G. (2018). Willingness to pay for preferred seat selection on UK domestic flights. Journal of Air Transport Management, 70, 57-61.

71. Ryan, C., \& Birks, S. (2006). Passengers and low cost flights: evidence from the Trans-Tasman routes. Journal of Travel \& Tourism Marketing, 19(1), 15-27.

72. Shrestha, R. K., \& Alavalapati, J. R. (2004). Valuing environmental benefits of silvopasture practice: a case study of the Lake Okeechobee watershed in Florida. Ecological Economics, 49(3), 349-359.

73. Simonson, I., \& Drolet, A. (2004). Anchoring effects on consumers' willingnessto-pay and willingness-to-accept. Journal of consumer research, 31(3), 681-690.

74. Stichhauerova, E., \& Pelloneova, N. (2019). An Efficiency Assessment of Selected German Airports Using the DEA Model. Journal of Competitiveness, 11(1), 135-151.

75. Teichert, T., Shehu, E., \& von Wartburg, I. (2008). Customer segmentation revisited: The case of the airline industry. Transportation Research Part A: Policy and Practice, 42(1), 227-242.

76. Thurstone, L. L. (1994). A law of comparative judgment. Psychological Review, 101(2), 266.

77. Van Cranenburgh, S., Chorus, C. G., \& Van Wee, B. (2014). Vacation behaviour under high travel cost conditions-a stated preference of revealed preference approach. Tourism Management, 43, 105-118.

78. Vlachos, I., \& Lin, Z. (2014). Drivers of airline loyalty: Evidence from the business travelers in China. Transportation Research Part E: Logistics and Transportation Review, 71, 1-17.

79. Wensveen, J. G., \& Leick, R. (2009). The long-haul low-cost carrier: A unique business model. Journal of Air Transport Management, 15(3), 127-133.

80. Wu, C. L., \& So, T. H. (2018). On the flight choice behaviour of business-purpose passengers in the Australian domestic air market. Journal of Air Transport Management, 72, 56-67.

81. Yaylali, M., Çelik, A. K., \& Dilek, Ö. (2016). Analyzing key socio-economic and socio-demographic drivers of domestic passengers' airline choice behavior in Turkey using multinomial and mixed logit models. Transportation Letters, 8(3), 121-130. 
82. Yoo, K. E., \& Ashford, N. (1996). Carrier choices of air passengers in pacific rim: Using comparative analysis and complementary interpretation of revealed preference and stated preference data. Transportation Research Record, 1562(1), $1-7$.

83. Zhang, A., Hanaoka, S., Inamura, H., \& Ishikura, T. (2017). Low-cost carriers in Asia: Deregulation, regional liberalization and secondary airports. In Low Cost Carriers (pp. 55-69). Routledge.

\section{Brief description of Author/Authors:}

\section{Sanaz Vatankhah}

Department of Management, Ahvaz Branch, Islamic Azad University, Ahvaz, Iran. Email: sanaz-vatankhah@iauahvaz.ac.ir

Sanaz Vatankhah is a $\mathrm{PhD}$. candidate in business administration, specializing in marketing management. She is currently based in Islamic Azad University, Ahvaz branch, Iran. She holds Master of Science in tourism management and Bachelor of Science in tourism and hospitality management. Her area of research includes service marketing, Aviation and transportation business and operation, high-performance work practices, organizational deviant behavior. She has publications in journal of Air Transport Management, Tourism management, Tourism review and the journal of human resources in hospitality and tourism.

\section{Professor Dr. Mansour Zarra-Nezhad}

Department of Economics, Shahid Chamran university of Ahvaz, Ahvaz, Iran.

E-mail: m.zarran@scu.ac.ir

Mansour Zarra-Nezhad is a professor of economics and the dean of the Faculty of economics and social sciences, Shahid Chamran University, Iran. His research mainly focuses on economics, econometrics, Islamic Economics and Financial Economics. He has several publications in The International Journal of Applied Economics and Finance, Journal of Hospitality and Tourism Management, Tourism management, Journal of Social Science and Asian Economic and Financial Review.

\section{Assisstant Prof. Dr. Ghanbar Amirnejad}

Department of Management, Shushtar Branch, Islamic Azad University, Shushtar, Iran. Email: g.amirnejad@yahoo.com 
Appendix A review on WTP and WTA air transport services

\begin{tabular}{|c|c|c|c|}
\hline Authors & Significant concern & Method & Attributes \\
\hline $\begin{array}{l}\text { Lu \& Shon } \\
\text { (2012) }\end{array}$ & $\begin{array}{l}\text { There has been only a little number of studies looking at } \\
\text { how much air passengers would be willing to pay for the } \\
\text { carbon offsets, what factors determine their willingness to } \\
\text { pay (WTP), and the consequences of implementing the } \\
\text { carbon tax. (p. 124) }\end{array}$ & $\begin{array}{l}\text { Contingent valuation } \\
\text { method }\end{array}$ & $\begin{array}{l}\text { Trip characteristic } \\
\text { Perceptions of "Carbon-offset scheme", } \\
\text { Personal background }\end{array}$ \\
\hline $\begin{array}{l}\text { Kurtulmuşoğlu } \\
\text { et al. (2016) }\end{array}$ & $\begin{array}{l}\text { The airline operating based on a low-cost model that allows } \\
\text { passengers to choose additional services for additional } \\
\text { charges were found as the most preferred airline. }\end{array}$ & $\begin{array}{l}\text { Stochastic Multi- } \\
\text { criteria Acceptability } \\
\text { Analysis-2 (SMAA-2) } \\
\text { method }\end{array}$ & $\begin{array}{l}\text { The convenience of the flight schedule, In-flight food and } \\
\text { beverages, Ticket price, In-flight entertainment, In-flight seat space, } \\
\text { Sufficient air conditioning, Cleanliness of the plane, Punctuality, } \\
\text { On-time performance, The variety and quality of food and } \\
\text { beverages, Ease of booking, Customized needs of customers, } \\
\text { Online booking, Safe and careful baggage handling, Customer } \\
\text { complaint handling, Voyager miles, The reward campaigns for } \\
\text { loyal customers, Facilities for disabled passengers and for pregnant } \\
\text { and elderly passengers, Courtesy and responsiveness, Genuine } \\
\text { interest in solving problems, Caring and friendly crews, Cabin crew } \\
\text { service, Professional appearance of flight crew, Flight safety, User } \\
\text { friendly and comprehensive website, Promptness and accuracy of } \\
\text { customer services, Flight frequency. }\end{array}$ \\
\hline $\begin{array}{l}\text { O’Connell \& } \\
\text { Warnock-Smith } \\
\text { (2013) }\end{array}$ & $\begin{array}{l}\text { "Airport car parking and checked baggage charges proved } \\
\text { to be the most accepted commission based and unbundled } \\
\text { products for airlines to sell respectively". (p.12) }\end{array}$ & $\begin{array}{l}\text { on-line traveler survey } \\
\text { expert opinion }\end{array}$ & $\begin{array}{l}\text { Travel Insurance, Accommodation, Airport parking, Car Hire, } \\
\text { Surface transport, Attractions, }\end{array}$ \\
\hline $\begin{array}{l}\text { Balcombe } \\
\text { Fraser \& Harris } \\
\quad(2009)\end{array}$ & $\begin{array}{l}\text { They consider "which attributes of in-flight cabin comfort } \\
\text { and service may have a value to consumers by analyzing } \\
\text { consumer willingness to pay (WTP) for in-flight attributes". } \\
\text { (p. 221) }\end{array}$ & $\begin{array}{l}\text { Bayesian methods \& } \\
\text { mixed logit } \\
\text { specification }\end{array}$ & $\begin{array}{l}\text { Seat Pitch, Seat Width, In-Flight Meal, In-Flight Entertainment, } \\
\text { Complementary in-Flight Drinks, Ticket Prices. }\end{array}$ \\
\hline $\begin{array}{l}\text { Chen \& Wu } \\
\text { (2009) }\end{array}$ & $\begin{array}{l}\text { Regarding low-cost carriers in Taiwan "meal service price } \\
\text { for non-business traveler model is much higher than that for }\end{array}$ & random utility & $\begin{array}{l}\text { Fare, Meal service, Entertainment service, Booking channel, Flight } \\
\text { change. }\end{array}$ \\
\hline
\end{tabular}




\begin{tabular}{|c|c|c|c|}
\hline & $\begin{array}{l}\text { business traveler model while the importance of flight } \\
\text { change availability for business traveler. (p. 53) } \\
\text { model is reversely much higher than that for non-business } \\
\text { traveler } \\
\text { model. }\end{array}$ & $\begin{array}{l}\text { model, stated } \\
\text { preference analysis, } \\
\text { logit model. }\end{array}$ & \\
\hline $\begin{array}{l}\text { Kou \& Jou } \\
\text { (2017) }\end{array}$ & $\begin{array}{l}\text { Existing literature dose not adequately address passengers' } \\
\text { willingness to pay for premium economy class }\end{array}$ & $\begin{array}{l}\text { random utility theory, } \\
\text { Contingent Value } \\
\text { Method, spike model }\end{array}$ & $\begin{array}{l}\text { seat pitch and width, ticket price, experience in premium economy } \\
\text { class, experience in premium economy class, free baggage } \\
\text { allowance, dedicated check-in counters, travel necessities supply, } \\
\text { premium economy class understandability, seat pitch and width. }\end{array}$ \\
\hline $\begin{array}{l}\text { Chang \& Sun } \\
\text { (2012) }\end{array}$ & $\begin{array}{l}\text { Choosing a low-cost carrier in Taiwan is based on } \\
\text { passengers socio economic characteristics and travel } \\
\text { experiences. Particularly, "Non-business travelers tend to } \\
\text { be more willing than business travelers to pay more for } \\
\text { luggage service and daytime arrival, and in particular they } \\
\text { are more willing to use a secondary airport. }\end{array}$ & $\begin{array}{l}\text { stated-choice } \\
\text { modeling, multinomial } \\
\text { probabilistic choice } \\
\text { model, multinomial } \\
\text { logit model }\end{array}$ & $\begin{array}{l}\text { Fare, Luggage restriction, Service frequency per day, Arrival time, } \\
\text { Destination airport. }\end{array}$ \\
\hline $\begin{array}{l}\text { Curras-Perez \& } \\
\text { Sanchez-Garcia } \\
\quad(2015)\end{array}$ & $\begin{array}{l}\text { "Although customer loyalty has been a recurrent topic in the } \\
\text { marketing literature, the main determinants of such loyalty } \\
\text { in the airline industry remain unclear, especially where low- } \\
\text { cost carriers are concerned" (p. 2) }\end{array}$ & $\begin{array}{l}\text { Survey, Confirmatory } \\
\text { factor analysis, } \\
\text { structural equation } \\
\text { analysis. }\end{array}$ & 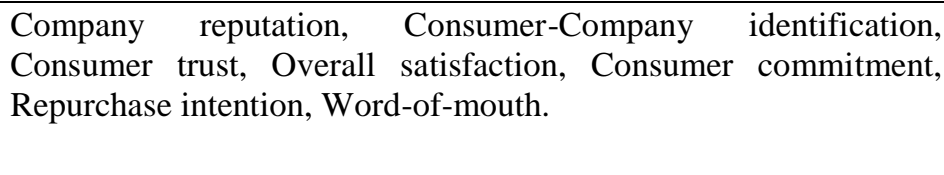 \\
\hline Rajaguru (2016) & $\begin{array}{l}\text { "There is an ambiguity and little evidences in literature that } \\
\text { explore how the airline type interact with value for money } \\
\text { and service quality and influences consumer satisfaction } \\
\text { and behavioral intention (p. 114) }\end{array}$ & $\begin{array}{l}\text { Survey, Confirmatory } \\
\text { factor analysis, } \\
\text { structural equation } \\
\text { analysis. }\end{array}$ & $\begin{array}{l}\text { Value for money, service quality, customer satisfaction, behavioral } \\
\text { intention. }\end{array}$ \\
\hline $\begin{array}{l}\text { Vlachos \& } \\
\text { Lin (2014) }\end{array}$ & $\begin{array}{l}\text { Relative literature concerning passenger loyalty in airline } \\
\text { industry and "research into factors driving passenger loyalty } \\
\text { is still at its early stage, and findings so far have been } \\
\text { inconclusive" (p. 1). Accordingly, key airline attributes } \\
\text { affecting passengers" loyalty are proposed. }\end{array}$ & $\begin{array}{l}\text { Panel interview, } \\
\text { literature review. }\end{array}$ & $\begin{array}{l}\text { Operational factors: safety, punctuality, aircraft; Competitive } \\
\text { Factors: Frequency of flights, Schedule, Frequent flyer program, } \\
\text { Ticket price, Reputation; Attractive factors: In-flight food \& drinks, } \\
\text { In-flight staff service. }\end{array}$ \\
\hline
\end{tabular}




\begin{tabular}{|c|c|c|c|}
\hline $\begin{array}{l}\text { Akamai, } \\
\text { et al. } \\
(2015)\end{array}$ & $\begin{array}{l}\text { "Given the intensive rivalry in the transport industry, } \\
\text { passenger relationship management has become a vital } \\
\text { concern for the low-cost airline (LCA) sector. However, } \\
\text { determinants of LCA passenger loyalty, such as service } \\
\text { employee self-efficacy, price, service recovery, passenger } \\
\text { trust and satisfaction, are overlooked" (p. 528). accordingly, } \\
\text { key antecedents' effect on LCA passenger loyalty are } \\
\text { examined. }\end{array}$ & $\begin{array}{l}\text { Survey, Confirmatory } \\
\text { factor analysis, } \\
\text { structural equation } \\
\text { analysis. }\end{array}$ & $\begin{array}{l}\text { Service recovery, Passenger loyalty, Passenger trust, Passenger } \\
\text { satisfaction, Service employees Self efficacy, Price. }\end{array}$ \\
\hline $\begin{array}{l}\text { Jung, Han \& Oh } \\
\text { (2017) }\end{array}$ & $\begin{array}{l}\text { "No research has ever examined or identified antecedent } \\
\text { variable for switching behavior and their impact on in } \\
\text { building customers' intentions to switch, particularly in the } \\
\text { airline industry" (p. 140). }\end{array}$ & $\begin{array}{l}\text { extensive review of } \\
\text { the literature and } \\
\text { open-ended survey } \\
\text { based on Migration } \\
\text { theory and Push-Pull- } \\
\text { Mooring model; } \\
\text { Confirmatory factor } \\
\text { analysis, structural } \\
\text { equation analysis. }\end{array}$ & $\begin{array}{l}\text { Push factors: low service quality, price problems, low satisfaction, } \\
\text { low trust; Pull factors: attractiveness of alternatives, opportunity for } \\
\text { alternatives, price benefits; Mooring factors: high switching cost, } \\
\text { low variety seeking, low prior switching experience, involuntary } \\
\text { choice; switching intention. }\end{array}$ \\
\hline $\begin{array}{c}\text { Hagmann, } \\
\text { Semeijn \& } \\
\text { Vellenga (2015) }\end{array}$ & $\begin{array}{l}\text { "During the last few years there has been an increasing trend } \\
\text { for companies to market their products or services as green } \\
\text { or environmentally friendly as part of their corporate social } \\
\text { responsibility. Few studies have analyzed the effects of this } \\
\text { recent focus on the environment and its impact on airline } \\
\text { passengers" (p.37). Accordingly, passengers' general } \\
\text { attitudes regarding greener airlines are addressed. }\end{array}$ & $\begin{array}{l}\text { Survey, willingness to } \\
\text { pay for the green } \\
\text { component, Paired t- } \\
\text { test, One-way } \\
\text { ANOVA, Independent } \\
\text { samples t-test, Pearson } \\
\text { Correlation. }\end{array}$ & $\begin{array}{l}\text { price, flight time, seat pitch and CO2 emissions, air travel behavior, } \\
\text { No stopover, Safety, Time travel, Green fleet, Green connection, } \\
\text { Green attitude, Seat space, Nationality, Green compensation, Green } \\
\text { initiatives, Frequent flyer } \\
\text { program }\end{array}$ \\
\hline $\begin{array}{l}\text { Milioti, et al. } \\
\quad(2015)\end{array}$ & $\begin{array}{l}\text { "Fare, safety and reliability, and friendly-and-helpful staff } \\
\text { during flight are the most important determinants of airline } \\
\text { choice" (p.46). respondents were also different in the } \\
\text { significance of above-mentioned factors conditioned on } \\
\text { their socio-demographic and trip characteristics. }\end{array}$ & $\begin{array}{l}\text { multivariate probit } \\
\text { model }\end{array}$ & $\begin{array}{l}\text { Fare, Flight schedule, Frequent flyer program, Connections until } \\
\text { destination, Large number of the cities served, Friend's/Agent's } \\
\text { recommendation, Friendly and helpful staff in flight, In-flight } \\
\text { entertainment, the whole airline's image, Airline, Final destination, } \\
\text { one-way trip, Mode of transport used, Connection to another airline, } \\
\text { booking method, who paid, Price of the ticket, Purpose of the } \\
\text { journey, Age, Gender, Nationality, Education, Monthly income, } \\
\text { Employment. }\end{array}$ \\
\hline
\end{tabular}




\begin{tabular}{|c|c|c|c|}
\hline Jeng (2016) & $\begin{array}{l}\text { Considering airline industry as a component of service } \\
\text { sector "brand credibility and its effect on consumer response } \\
\text { has received little attention" (p. 1) }\end{array}$ & $\begin{array}{l}\text { Structural equation } \\
\text { model }\end{array}$ & $\begin{array}{l}\text { brand credibility, decision convenience, affective commitment and } \\
\text { purchase intention. }\end{array}$ \\
\hline $\begin{array}{l}\text { Jiang \& Zhang } \\
\text { (2016) }\end{array}$ & $\begin{array}{l}\text { "Customer loyalty is a source of competitive advantage and } \\
\text { an important intangible asset to any organizations, but } \\
\text { empirical evidence from China's airline market regarding } \\
\text { the determinants of passenger satisfaction and loyalty is } \\
\text { lacking" (p.80) }\end{array}$ & Probit model & $\begin{array}{l}\text { In-flight entertainment, FFP, airline response to flight delay and } \\
\text { passenger complaints, Departure and arrival experiences, in-flight } \\
\text { comfort and cabin crew professionalism, Flight selection and ticket } \\
\text { purchase experience, Flight schedule, Convenience/efficiency of } \\
\text { check-in, Baggage allowances/ handling, Seat choice, Courtesy of } \\
\text { Check-in employee, Self-check-in facilities, Check-in information, } \\
\text { Boarding announcement, Facilities at airport lounge, Boarding } \\
\text { process, Courtesy of boarding employee, Special services for } \\
\text { children/disabled travelers, Comfort of aircraft seat, Courtesy of } \\
\text { flights attendants, Capability and helpfulness of flight attendants, } \\
\text { Cabin safety demonstration/ captain's announcement, Newspapers } \\
\text { and magazines on board, In-flight entertainment, shopping and food } \\
\text { and drinks, Convenience of baggage claim, Ground services on } \\
\text { arrival, FFP, punctuality, Demographics, travel experiences. }\end{array}$ \\
\hline $\begin{array}{l}\text { Ong \& Tan } \\
\quad(2010)\end{array}$ & $\begin{array}{l}\text { Results of a case study associated with Air Asia and } \\
\text { Malaysia airlines revealed that, "consumers" socio- } \\
\text { demographics (ethnicity and education level) and } \\
\text { behavioral choices (concerns over schedules and airfares, } \\
\text { routes, booking methods and purpose of journey) are } \\
\text { important determinants of airline choice" (p. 212). }\end{array}$ & $\begin{array}{l}\text { dichotomous-choice } \\
\text { response question, } \\
\text { logit analysis. }\end{array}$ & $\begin{array}{l}\text { Socio-demographic characteristics, concerns for airfare, concerns } \\
\text { for flight schedule, method of booking, purpose of travel, } \\
\text { destinations of travel. }\end{array}$ \\
\hline $\begin{array}{l}\text { Rose, Hensher } \\
\text { \& Greene } \\
\text { (2005) }\end{array}$ & $\begin{array}{l}\text { Considering the process by which passengers collect and } \\
\text { use information regarding airline choice, "the impact of } \\
\text { individual-specific attribute processing strategies (APS) on } \\
\text { the inclusion/exclusion of attributes on the parameter } \\
\text { estimates and behavioral outputs of models of airline service } \\
\text { and fare level choice" (p. 2) is examined. }\end{array}$ & $\begin{array}{l}\text { Random utility theory, } \\
\text { stated preference } \\
\text { choice experiment, } \\
\text { multinomial and } \\
\text { mixed logit model. }\end{array}$ & $\begin{array}{l}\text { Ticket Price, Flight Time (minutes), Departure Time, Flight Time } \\
\text { Variability, respondents' demographic characteristics. }\end{array}$ \\
\hline $\begin{array}{l}\text { Jung \& Yoo } \\
\quad(2014)\end{array}$ & $\begin{array}{l}\text { Low-cost carriers are able to generate "new demand by } \\
\text { attracting customers who would not have otherwise chosen } \\
\text { to pay higher air fares". To compete in this growing market, } \\
\text { hence, it is important for relative managers and planners "to }\end{array}$ & $\begin{array}{l}\text { Stated preference } \\
\text { choice experiment, } \\
\text { multinomial and } \\
\text { nested logit model. }\end{array}$ & Ticket fare, access time, frequency, journey time. \\
\hline
\end{tabular}




\begin{tabular}{|c|c|c|c|}
\hline & $\begin{array}{l}\text { know how passengers decide on their preferred method of } \\
\text { travel" (p.43). }\end{array}$ & & \\
\hline $\begin{array}{l}\text { Hess, et al. } \\
\quad(2007)\end{array}$ & $\begin{array}{l}\text { The use of discrete choice models to study air travel choice } \\
\text { behavior are increasing, of which stated preference survey } \\
\text { is significantly considered as an appropriate method to study } \\
\text { air travel choice. }\end{array}$ & $\begin{array}{l}\text { Stated preference } \\
\text { survey data, discrete } \\
\text { choice model, } \\
\text { multinomial logit } \\
\text { model. }\end{array}$ & $\begin{array}{l}\text { Airline and airport, flight time, number of connections, air fare, } \\
\text { arrival time, aircraft type, on-time performance of the various } \\
\text { flights, socio-demographic characteristics. }\end{array}$ \\
\hline $\begin{array}{l}\text { Espino, Martín } \\
\text { \& Román } \\
\text { (2008) }\end{array}$ & $\begin{array}{l}\text { "the willingness to pay using mixed logit models are lower } \\
\text { than those obtained from multinomial logit specifications. } \\
\text { That means that preference heterogeneity needs to be } \\
\text { considered in order to properly estimate the willingness to } \\
\text { pay measures for service quality changes because if taste } \\
\text { heterogeneity is important and neglected, the willingness to } \\
\text { pay measures can be highly overestimated" (p.593). }\end{array}$ & $\begin{array}{l}\text { Stated preference } \\
\text { survey data, discrete } \\
\text { choice model, } \\
\text { multinomial and } \\
\text { mixed logit model. }\end{array}$ & $\begin{array}{l}\text { socio-economic characteristics, price, penalty for changes in the } \\
\text { ticket, free food on board, comfort, frequency, reliability, } \\
\text { willingness-to-pay measures for service quality improvements. }\end{array}$ \\
\hline Hess (2008) & $\begin{array}{l}\text { Noting the rising use of stated choice (SC) data in studying } \\
\text { air travel choice behavior, "studies using SC data have the } \\
\text { advantage of being based on accurate records of all } \\
\text { information presented to respondents, which is not generally } \\
\text { the case with RP data" (p. 275) which makes this technique } \\
\text { more accurate in estimating the significance of attributes } \\
\text { such as fare and FFP. }\end{array}$ & $\begin{array}{l}\text { Stated preference } \\
\text { survey data, discrete } \\
\text { choice model, utility } \\
\text { function. }\end{array}$ & $\begin{array}{l}\text { socio-demographic information, last air trip behavior, access time, } \\
\text { flight time, number of connections, air fare, arrival time, the aircraft } \\
\text { type and on-time performance of the various services. }\end{array}$ \\
\hline $\begin{array}{l}\text { Wu \& So } \\
(2018)\end{array}$ & $\begin{array}{l}\text { "With the increasing demand of air travel for business } \\
\text { purposes, airlines are increasing the number of products } \\
\text { being offered in order to remain competitive. Hence, there } \\
\text { is an incentive for airlines to further explore the choice } \\
\text { behavior of passengers in the business travel category" } \\
\text { (p.56). }\end{array}$ & $\begin{array}{l}\text { Discrete choice } \\
\text { models, stated } \\
\text { preference, } \\
\text { multinomial logit } \\
\text { model. }\end{array}$ & $\begin{array}{l}\text { socio-demographic characteristics, fare, frequent flyer points, } \\
\text { checked baggage, on board food and beverage, advanced seat } \\
\text { selection, seat pitch and comfort, surcharge for changes/ticket } \\
\text { cancellation. }\end{array}$ \\
\hline $\begin{array}{l}\text { Medina-Muñoz } \\
\text { et al. (2018) }\end{array}$ & $\begin{array}{l}\text { "The attractiveness of airlines is a topic of great interest to } \\
\text { researchers and professionals wishing to understand the } \\
\text { ability of airlines to attract and satisfy air passengers. } \\
\text { However, there is a lack of consensus on which attributes of } \\
\text { the airline are important for attracting and satisfying } \\
\text { passengers" (p.45). }\end{array}$ & $\begin{array}{l}\text { principal component } \\
\text { analysis, varimax } \\
\text { rotation, confirmatory } \\
\text { factor analysis, one- } \\
\text { way analysis of } \\
\text { variance, Tukey's test, } \\
\text { t-test, } \\
\end{array}$ & $\begin{array}{l}\text { socio-demographic characteristics, airline attributes categories: } \\
\text { ticket price and promotional prices, additional charges, } \\
\text { service/price ratio, reservation channels and payment methods, } \\
\text { flight conditions (schedule, frequency, connections), in-flight } \\
\text { service, cabin facilities, ground services, airline operation, } \\
\text { professionalism of personnel, a passenger's feeling regarding a } \\
\text { particular airline, airline marketing and strategy }\end{array}$ \\
\hline
\end{tabular}




\begin{tabular}{|c|c|c|c|}
\hline Escobari (2017) & $\begin{array}{l}\text { Demand system estimation is considered as a crucial source } \\
\text { of differentiation in the airline industry which calls for a } \\
\text { close understanding of passengers" choice. "Studying } \\
\text { airline choice and substitution patterns is important because } \\
\text { airlines need to know the degree in which increasing their } \\
\text { prices shifts passengers to alternative carriers" (p.199). }\end{array}$ & $\begin{array}{l}\text { random-coefficients } \\
\text { logit methodology, } \\
\text { revealed preference } \\
\text { data, }\end{array}$ & Price, time to flight, departure time, airport, airline, departure time. \\
\hline $\begin{array}{l}\text { Rouncivell, } \\
\text { Timmis, \& Ison } \\
\quad(2018)\end{array}$ & $\begin{array}{l}\text { The airline industry is enjoying increasing ancillary revenue } \\
\text { in terms of more complex products and services. "Despite } \\
\text { the growing importance of ancillary revenue to the airline } \\
\text { industry business model, academic research to date has been } \\
\text { limited" (p. 58). }\end{array}$ & $\begin{array}{l}\text { Willingness to pay, } \\
\text { stated preference } \\
\text { method, Pearson } \\
\text { bivariate correlation } \\
\text { test. }\end{array}$ & $\begin{array}{l}\text { airline reputation, frequent flyer program, ticket price, price of } \\
\text { ancillary products, flight times and convenience of connections, } \\
\text { preferred seat. }\end{array}$ \\
\hline $\begin{array}{l}\text { Lhéritier, et al. } \\
\qquad(2018)\end{array}$ & $\begin{array}{l}\text { The knowledge of passengers' preferences while choosing } \\
\text { an airline "can help travel providers, either airlines or travel } \\
\text { agents, to better adapt their offer to market conditions and } \\
\text { customer needs" (p.1). }\end{array}$ & $\begin{array}{l}\text { non-parametric } \\
\text { machine learning, } \\
\text { Latent class } \\
\text { multinomial logit } \\
\text { model, Supervised } \\
\text { learning, Random } \\
\quad \text { forests. }\end{array}$ & $\begin{array}{l}\text { Price, trip duration, stay duration, departure time, arrival time, } \\
\text { origin, destination, direct flight, interline, }\end{array}$ \\
\hline $\begin{array}{l}\text { Koo, et al. } \\
\quad(2018)\end{array}$ & $\begin{array}{l}\text { "Knowing what factors influence people's choices of } \\
\text { airlines is important for many domains of interest within } \\
\text { aviation, and in transportation research more generally" (p. } \\
\text { 160) of which information on recent accidents has been } \\
\text { found important in choosing an airline. }\end{array}$ & $\begin{array}{l}\text { stated choice } \\
\text { experiments, } \\
\text { conditional, mixed and } \\
\text { latent class logit } \\
\text { model. }\end{array}$ & $\begin{array}{l}\text { socio-demographic characteristics, price, safety, reputation, flight } \\
\text { time, schedule, service. }\end{array}$ \\
\hline
\end{tabular}

